\title{
Case history and persistence of the non-indigenous diatom Coscinodiscus wailesii in the north-east Atlantic
}

\author{
M. Edwards* ${ }^{\dagger}$, A.W.G. John*, D.G. Johns* and P.C. Reid* \\ *Sir Alister Hardy Foundation for Ocean Science, The Laboratory, Citadel Hill, Plymouth, PL1 2PB. \\ ${ }^{\dagger}$ Department of Biological Sciences, University of Plymouth, Drake Circus, Plymouth, PL4 8AA. \\ E-mail: maed@wpo.nerc.ac.uk
}

\begin{abstract}
The introduction of non-indigenous marine plankton species can have a considerable ecological and economic effect on regional systems. Their presence, however, can go unnoticed until they reach nuisance status and as a consequence few case histories exist containing information on their initial appearance and their spatio-temporal patterns. Here we report on the occurrence of the non-indigenous diatom Coscinodiscus wailesii in 1977 in the English Channel, its subsequent geographical spread into European shelf seas, and its persistence as a significant member of the diatom community in the north-east Atlantic from 1977-1995.
\end{abstract}

\section{INTRODUCTION}

During the last few decades the introduction and geographical spread of non-indigenous marine species has become increasingly topical, as the appearance of such species can have important ecological and economic consequences (Reid, 1997). Introductions have special significance for phytoplankton as they may be associated with harmful algal blooms which may have adverse effects on other marine life, as well as endangering human health via shellfish poisoning and respiratory illness and as potential carriers of infectious diseases (Tester et al., 1991; Hallegraeff \& Bolch, 1992; Epstein et al., 1995). Arising from growing concerns of the apparent increase in the occurrence of harmful algal blooms and species introductions, a number of international and national initiatives have recently been implemented to improve understanding and develop management and amelioration strategies.

The main vector for the dispersal of non-indigenous marine phytoplankton species via human activities is by the worldwide transportation of ships' ballast water and to a lesser extent aquacultural practices (Carlton \& Geller, 1993). The idea that exotic species were introduced by ships' ballast water was first postulated by Ostenfeld (1908) who observed a large new Indo-Pacific diatom Biddulphia (now Odontella) sinensis Greville in the North Sea, previously known from the Red Sea and the South China Sea. Since then a number of invasive diatom, dinoflagellate and flagellate species have been identified in the North Sea (see Nehring, 1998; Elbrächter, 1999; and Reise et al., 1999 for comprehensive lists) and in the English Channel (Boalch, 1987a,b, 1994). Nehring (1998) and Boalch (1987b) noticed that while many new arrivals can be classified as temporary immigrants and initially may have an impact on the ecosystem, they often become rather localized (e.g. along frontal boundaries), disappear, or occupy an insignificant part of the community once balance has been restored. However, this is not the ecological fate for all invasive phytoplankton species, with some species becoming permanently established immi- grants. Here we report on one such species, the nonindigenous diatom Coscinodiscus wailesii Gran \& Angst, from its initial appearance, its subsequent geographical spread, and its recent persistence as a significant member of the diatom community in the North Sea.

Efforts to assess and monitor invasive marine species are at best fragmented, as they are typically only monitored or first noticed when the species reaches nuisance status (Hallegraeff, 1993) and as a consequence few case histories exist containing information of their spatial and temporal trends. Continuous Plankton Recorder (CPR) samples have been taken at a depth of $10 \mathrm{~m}$ in the North Atlantic Ocean from 1931 to 1939 and 1946 to the present. The CPR survey samples at monthly intervals over major regions of the North Atlantic Ocean and routinely identifies approximately 400 taxa of phytoplankton and zooplankton (Warner \& Hays, 1994). Sampling by the CPR survey in the North Sea provides a comprehensive geographical network, allowing the systematic monitoring of changes in the plankton community in both space and time.

\section{RESULTS AND DISCUSSION}

Coscinodiscus wailesii is a very large centric diatom (175$500 \mu \mathrm{m}$ in diameter) which was originally only known from essentially two regions, the first includes the Pacific coast of North America from southern California to British Columbia (Mahoney \& Steimle, 1980) and the second includes areas of the Sea of China and Japanese coastal waters of the North Pacific Ocean (Kokubo, 1952; Nagai et al., 1995). The first occurrence of C.wailesii in the north-east Atlantic Ocean was reported by Boalch \& Harbour (1977), who at the time identified it as C.nobilis Grunow. It was found in the Western Approaches of the English Channel from plankton samples taken just off Plymouth in January 1977. Plankton samples have been taken by the CPR survey at monthly intervals since the early 1950s in the Western Approaches and C. wailesii was first recorded in CPR samples (as C.nobilis) at $49^{\circ} 57^{\prime} \mathrm{N}$ 
A
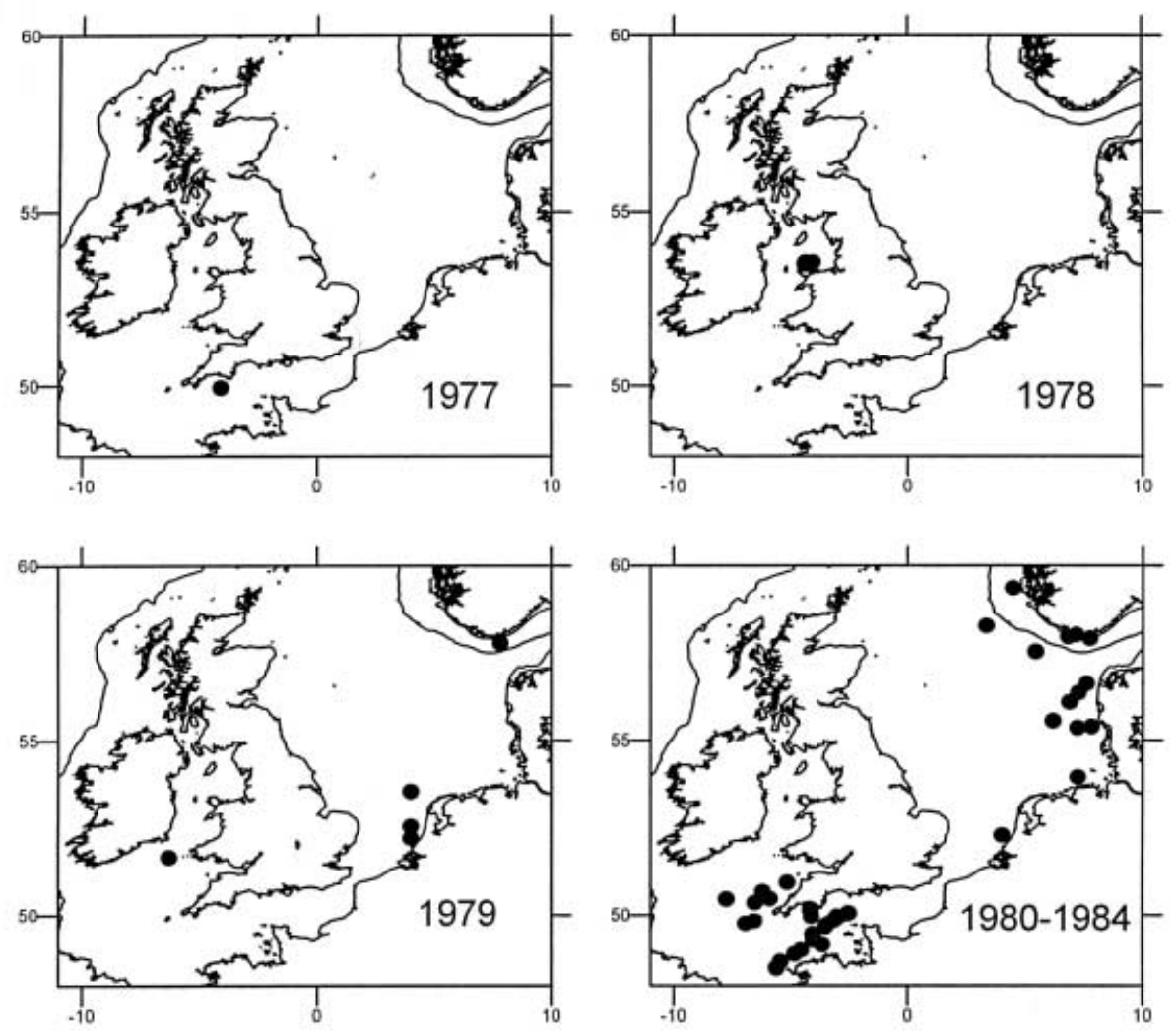

B
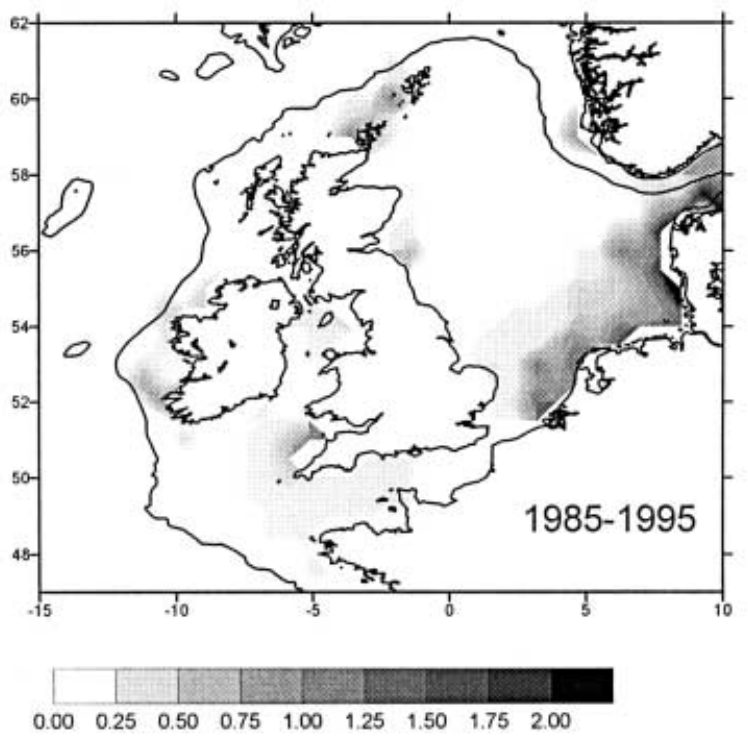

Log-abundance

Figure 1. (A) Geographical distribution of Coscinodiscus wailesii in CPR samples in 1977, 1978, 1979 and from 1980 to 1984 in the north-east Atlantic; (B) geostatistical estimates of the mean $\log$ abundance of C.wailesii in CPR samples in the north-east Atlantic between 1985 and 1995. Density equates to log mean cell count per sample $\left(\sim 3 \mathrm{~m}^{3}\right)$.

$04^{\circ} 06^{\prime} \mathrm{W}$ (Figure 1A) in the spring of 1977 (Robinson et al., 1980). It is suspected that it was brought about by ballast water transport, although another potential vector may be via the importation of oysters from Japan and North America (Rince \& Paulmier, 1986; Reise et al., 1999).

In 1978, C. wailesii first appeared in CPR samples in June and July in the northern Irish Sea, presumably carried north by current systems in the English Channel and Irish Sea. By 1979, C. wailesii had entered the North Sea and was found off the Dutch coast and at the entrance to the Skagerrak (Figure 1A), finally establishing itself within the Baltic Sea by 1983. The species was not found in CPR samples taken off Plymouth in 1978 or 1979. During the early 1980s the species continued to occur in these initial areas of establishment and also spread further east along the English Channel and further south along the Atlantic coast of France. In the North Sea, C. wailesii was frequently recorded in German and Danish coastal waters and in the 
waters off southern Norway. During 1985, C.wailesii was found in two new areas of the north-east Atlantic Ocean, off the south and west coasts of Ireland and in northern coastal waters of Scotland, principally around the Shetland and Orkney Islands. Outside the CPR survey's sampling network, C.wailesii has been recorded as far south as $46^{\circ} \mathrm{N}$, along the Atlantic coast of France (Rince \& Paulmier, 1986) and along the Norwegian coast to a northerly limit of $64^{\circ} \mathrm{N}$ (Karl Tangen, personal communication).

Successful invasions in aquatic systems may occur when native assemblages of organisms have been temporally disrupted by anomalous environmental conditions. This may be a determining factor in permanent establishment, particularly at the earliest stages of invasion. The North Sea shows considerable seasonal temporal disruption, with oceanic species sporadically entering the North Sea as a consequence of oceanic inflow. These species are simply extending their geographical range in response to changing environmental conditions and never establish permanent residence due to abiotic limitations once conditions return to normal. However, anomalous ocean climate conditions occur in the North Sea, which can persist for a number of years. One of the most anomalous periods in the North Sea over the last 40 years (both physically and biologically) occurred in the late 1970s. According to CPR survey records (data not shown), in the late 1970 s phytoplankton diversity was low and seasonal patterns were anomalous (caused primarily by a delay in the spring bloom and a retarded seasonal growth period). For example, many early spring diatom species were absent and one of the most abundant diatoms (Chaetoceros spp.), normally present in March/April, was only recorded in small numbers in August during 1979. Temporal niches normally occupied by particular species were, therefore, abnormal during this period. Similarly, one of the most dominant dinoflagellates (Ceratium macroceros) experienced a population crash from an average recorded frequency of $40 \%$ on CPR samples in the 1960 s to $0.4 \%$ during the late 1970 s. It is presently open to question whether this exceptional period in the North Sea, caused primarily by unusual boreal conditions, left the ecosystem more susceptible to invasions (i.e. biotic resistance was low), or that the appearance of Coscinodiscus wailesii around this time was purely coincidental.

Since 1985, C.wailesii has become well-established in European continental shelf seas and in certain regions has become a significant member of the phytoplankton community, particularly during spring and autumn. Highest abundance is found along the southern North Sea coast and in the entrance to the Skagerrak, with sizeable populations now existing along the south-west coast of Norway, the western English Channel/Celtic Sea and the Atlantic coast of France, the northern Irish Sea, the west coast of Ireland, the Firth of Forth and in the coastal waters around the Orkney and Shetland Islands (Figure 1B). Its rapid establishment and success along the European continental coast and in the German Bight is particularly noteworthy, as the species can dominate the phytoplankton biomass over long periods in this area. Rick \& Dürselen (1995) reported that during the period December 1988 to March 1989 the majority of phytoplankton carbon (up to $90 \%$ ) in the German Bight could be attributed to this species. One likely reason for the success of C.wailesii and its ability to establish itself in new areas probably stems from its tolerance of wide temperature (from $0^{\circ} \mathrm{C}$ to $>20^{\circ} \mathrm{C}$ ), salinity (24-35 psu) and nutrient regimes (Dürselen \& Rick, 1999).

Biogeographically the species appears to be most abundant in the neritic and well-mixed/transitional water masses of the north-east Atlantic Ocean. This is particularly apparent in the seasonally stratified northern North Sea, where the species is geographically restricted to transitional waters around the Orkney and Shetland Islands (see Pingree \& Griffiths, 1978 for the position of frontal boundaries around the British Isles). The seasonal cycle of C. wailesii in the southern North Sea (Figure 2A) shows that the species dominates during the spring and autumn blooms. Highest abundance is found in April and again in September and October, with minima occurring during the summer months. The most sustained growth occurs during the autumn months. The long-term changes in C.wailesii in the southern North Sea, however, do not follow any discernible trend, with the population oscillating in abundance from one year to the next (Figure 2B). Although the species was first recorded by the CPR in the southern North Sea during 1979, it was not until 1984 that the species became established there and relatively high numbers were first recorded. Since its appearance in 1979, high numbers have been recorded in 1985, 1989 and 1990 and again in 1993 (from CPR data 1977-1995). It is not yet known why this species is particularly successful in one year and not in another and whether this is due to biological or physical constraints.

The appearance of non-indigenous species within a region can have both an important economic and environmental impact and this is certainly the case for C.wailesii. Although the species is non-toxic, when it first appeared in the north-east Atlantic it had a detrimental effect on fishing operations (Boalch \& Harbour, 1977); this was also reported when the species was first recorded in the north-west Atlantic (Mahoney \& Steimle, 1980). The species is capable of producing copious amounts of mucilage during bloom conditions to such an extent that this can clog fishing nets (Boalch, 1987). In Japanese coastal waters the species is considered particularly noxious as it causes serious damage to Nori (Porphyra) culture by removing nutrients such as inorganic nitrogen during winter and spring (Nagai et al., 1995). Coscinodiscus wailesii can reach such a high abundance it can dominate the phytoplankton biomass and therefore could have potential effects on the whole ecosystem by out-competing native species for resources/space, reducing biodiversity (NRG, 1995) and affecting exploitation rates of its primary production by native consumers. There is already evidence that C.wailesii can supersede indigenous phytoplankton species under certain conditions (Dürselen \& Rick, 1999) and that two common indigenous herbivorous copepods of the southern North Sea find the species unpalatable (Roy et al., 1989).

In order to measure the ecological consequences of a non-indigenous species it is important to have base line information on the natural history of native species, and the community structure and biodiversity of the regional system under threat. Equally important is the ability to distinguish between community structural changes caused 

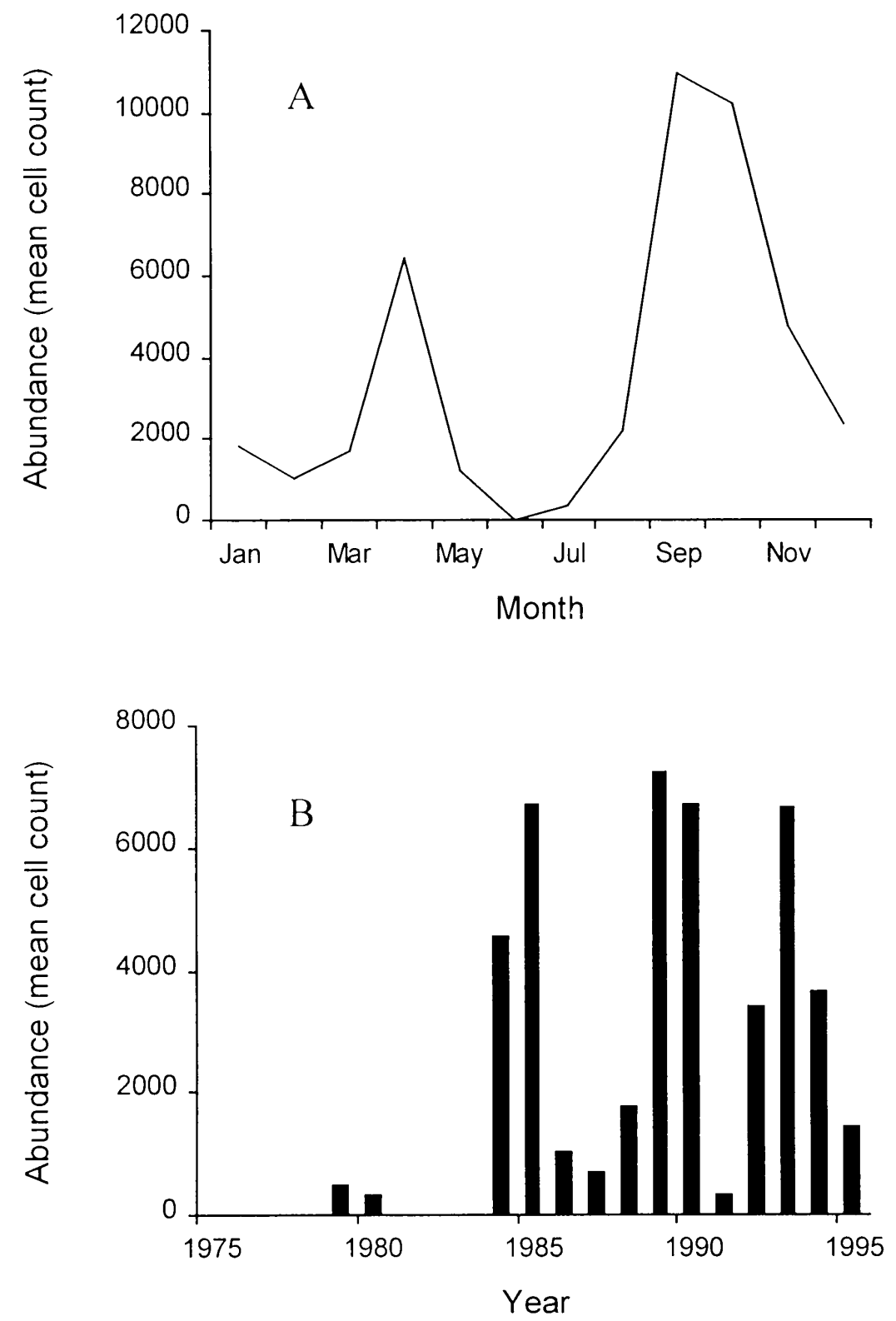

Figure 2. (A) Mean seasonal abundance of Coscinodiscus wailesii in CPR samples in the southern North Sea between 1985 and 1995. Density equates to mean cell count per sample $\left(\sim 3 \mathrm{~m}^{3}\right) ;(B)$ annual means of $C$. wailesii in CPR samples in the southern North Sea between 1975 and 1995. Density equates to mean cell count per sample $\left(\sim 3 \mathrm{~m}^{3}\right)$.

by invasive species and natural changes caused by climate variability. It has yet to be determined how much of the marked increase in phytoplankton biomass seen in the North Sea since 1985 (Reid et al., 1998) can be attributed to the increasing part that C.wailesii is now playing in the autumn and winter phytoplankton of the North Sea. This study is the first of its kind to show the spatial evolution of an invasive phytoplankton species over a decadal period. However, the consequences of shifting ecological roles in the North Sea in the long-term can only be determined by future observations. Whatever the source of phytoplankton introductions, measuring the patterns and rate of their spread is also essential in establishing the effectiveness of any management strategy put in place to limit invasions.

The CPR survey is supported by a funding consortium comprising: IOC, UNIDO, the European Commission and agencies from Canada, Denmark, Netherlands, UK and USA. The survey depends on the voluntary cooperation of owners, masters and crews of merchant vessels, which tow the CPRs on regular routes. We also wish to thank the CPR survey team past and present, Gerald Boalch for useful comments and Karl Tangen for providing information on Norwegian phytoplankton.

\section{REFERENCES}

Boalch, G.T., 1987a. Recent blooms in the western English Channel. Rapport et Procès-verbaux des Réunions. Conseil International pour l'Exploration de la Mer. Copenhague, 187, 94-97.

Boalch, G.T., 1987b. Changes in the phytoplankton of the western English Channel in recent years. British Phycological Fournal, 22, 225-235.

Boalch, G.T., 1994. The introduction of non-indigenous marine species to Europe: planktonic species. In Introduced species in European coastal waters (ed. C.F. Boudouresque et al.), pp. 2831. Brussels: European Commission. 
Boalch, G.T. \& Harbour, D.S., 1977. Unusual diatom off the coast of south-west England and its effect on fishing. Nature, London, 269, 687-688.

Carlton, J.T. \& Geller, J.B., 1993. Ecological roulette: the global transport of non-indigenous marine organisms. Science, New York, 261, 78-82.

Dürselen, C.-D. \& Rick, H.-J., 1999. Spatial and temporal distribution of two new phytoplankton diatom species in the German Bight in the period 1988 and 1996. Sarsia, 84, 367377.

Elbrächter, M., 1999. Exotic flagellates of coastal North Sea waters. Helgoländer Meeresuntersuchungen, 52, 235242.

Epstein, P.R., 1995. The role of algal blooms in the spread and persistence of human cholera. In Harmful marine algal blooms (ed. P. Lassus et al.), pp. 846. Paris: Lavoisier.

Hallegraeff, G.M., 1993. A review of harmful algal blooms and their apparent global increase. Phycologia, 32, 79-99.

Hallegraeff, G.M. \& Bolch, C.J., 1992. Transport of diatom and dinoflagellate resting spores in ships' ballast water: implications for plankton biogeography and aquaculture. Fournal of Plankton Research, 14, 1067-1084.

Kokubo, S., 1952. Results of the observations on the plankton and oceanography of Mutsu Bay during 1950, reference being made also to the period 1946-1950. Bulletin of the Marine Biological Station of Asamushi, 5, 1-54.

Mahoney, J.B. \& Steimle, F.W., 1980. Possible association of fishing gear clogging with a diatom bloom in the Middle Atlantic Bight. Bulletin of the New Fersey Academy of Science, 25, 18-21.

Nagai, S., Hori, Y., Manebe, T. \& Imai, I., 1995. Restoration of cell size by vegetative cell enlargement in Coscinodiscus wailesii (Bacillariophyceae). Phycologia, 34, 533-535.

National Research Council (NRG), 1995. Understanding marine biodiversity. Washington, DC: National Academic Press.

Nehring, S., 1998. Establishment of thermophilic phytoplankton species in the North Sea: biological indicators of climate change? ICES Fournal of Marine Science, 55, 818823.
Ostenfeld, C.H., 1908. On the immigration of Biddulphia sinensis Grev. and its occurrence in the North Sea during 1903-1907. Meddelelser Fra Kommissionen for Havunder-søgelser. Serie: Plankton, Kobenhavn, 1, 1-44.

Pingree, R.D. \& Griffiths, D.K., 1978. Tidal fronts in the shelf seas around the British Isles. Fournal of Geophysical Research, 83, 4615-4622.

Reid, P.C., 1997. Phytoplankton and anthropogenic influences: a review. Marine Environmental Management review of 1996 and future trends, 4, 113-118.

Reid, P.C., Edwards, M., Hunt, H.G. \& Warner, A.J., 1998. Phytoplankton change in the North Atlantic. Nature, London, 391, 546.

Reise, K., Gollasch, S. \& Wolf, W.J., 1999. Introduced marine species of the North Sea coasts. Helgoländer Meeresuntersuchungen, 52, 219-224.

Rick, H.-J. \& Dürselen, C.-D., 1995. Importance and abundance of the recently established species Coscinodiscus wailesii Gran \& Angst in the German Bight. Helgoländer Meeresuntersuchungen, 49, 355-374.

Rince, Y. \& Paulmier, G., 1986. Données nouvelles sur la distribution de la diatomée marine Coscinodiscus wailesii Gran \& Angst (Bacillariophyceae). Phycologia, 25, 73-79.

Robinson, G.A., Budd, T.D., John, A.W.G. \& Reid, P.C., 1980. Coscinodiscus nobilis (Grunow) in Continuous Plankton Records, 1977-1978. Fournal of the Marine Biological Association of the United Kingdom, 60, 675-680.

Roy, S., Harris, R.P. \& Poulet, S.A., 1989. Inefficient feeding by Calanus helgolandicus and Temora longicornis on Coscinodiscus wailesii: quantitative estimations using chlorophyll-type pigment and effects on dissolved free amino acids. Marine Ecology Progress Series, 52, 145-153.

Tester, P.A., Stumpf, R.P., Vukovich, F.M., Fowler, P.K. \& Turner, J.T., 1991. An expatriate red tide bloom: transport, distribution and persistence. Limnology and Oceanography, 36, 1053-1061.

Warner, A.J. \& Hays, G.C., 1994. Sampling by the Continuous Plankton Recorder survey. Progress in Oceanography, 34, 237-256.

Submitted 6 November 2000. Accepted 6 February 2001. 